\title{
Development of Skin Moisturizing Product Using Fermentation Technology of Plant Extracts
}

\author{
Bora Kwon, Young-Ji Choi, Mi Hee Kim, Kang Yeol Yu and Jiyoung Kim* \\ Jeonju Agro Bio-Materials Institute, Jeonju-Si, Korea \\ Received: 制: September 14, 2018; Published: 制 September 26, 2018 \\ *Corresponding author: Jiyoung Kim, Jeonju Agro Bio-Materials Institute, Jeonju-si, Korea
}

\section{Opinion}

Unlike medicines, cosmetics are not used to treat or prevent certain diseases. They are used daily for the beauty and health of human skin. Therefore, safety must be considered, and there should be no side effects in use [1]. Oriental cosmetics, which are oriented toward "well-being" that has become a global trend, satisfy the needs of consumers who prefer natural ingredients. They are believed to be effective as an anti-atopic or an anti-aging for skin health, and are considered suitable as a herbal cosmetic raw material. With the rise of some cosmetic stability problems, consumers' desire for safe and natural cosmetics has increased, and the most noteworthy of them is fermented ingredients. Since fermentation cosmetics utilize living organisms, it is possible to extract raw ingredients that are effective on the skin, and the size of the particles is reduced through the fermentation process, which is characteristic of high skin absorption rate [2,3]. Microorganisms and enzymes can be converted to substances with significantly improved functionality by removing sugars from the glycoside material present in the plant. As the microorganisms grow, nutrients that are good for the skin such as vitamins and organic acids are produced.

Women's skin is rapidly becoming dry, and the development of cosmetics with enhanced moisturizing function is required. Typical moisturizing ingredients used in moisturizing cosmetics include natural moisturizing factors and hyaluronic acid [4-7]. It is important to have a certain amount of moisture in the skin in order to remove various skin troubles and to maintain elastic skin. Equisetum arvense Linne. is a perennial plant [8]. It has an effect of inhibiting elastase activity and is effective in preventing aging of skin. It is effective in preventing dermatitis, swelling, skin eczema, prevention of hair loss and eliminating heat rash. It is said to be good for fatty skin and is said to soften and smooth the skin. When new materials are developed using fermentation technology, they exhibit completely new effects with existing materials or many harmful ingredients are converted into safe ingredients. Fermentation is a promising 21st century biotech industry that produces safe and efficacious products. Fermentation biotechnology may become a turning point for the development of highly functional fermented cosmetics.

\section{Acknowledgment}

This research was supported by the Ministry of Trade, Industry \& Energy (MOTIE), Korea Institute for Advancement of Technology (KIAT) through the Encouragement Program for The Industries of Economic Cooperation Region.

\section{References}

1. McDaniel D, Farris P, Valacchi G (2018) Atmospheric skin agingContributors and inhibitors. J Cosmet Dermatol 17(2): 124-137.

2. Borresen EC, Henderson AJ, Kumar A, Weir TL, Ryan EP, et al. (2012) Fermented foods: patented approaches and formulations for nutritional supplementation and health promotion. Recent Pat Food Nutr Agric 4: 134-140.

3. Zokaeifar H, Balcázar JL, Saad CR, Kamarudin MS, Sijam K, et al. (2012) Effects of Bacillus subtilis on the growth performance, digestive enzymes, immune gene expression and disease resistance of white shrimp, Litopenaeus vannamei. Fish Shellfish Immunol 33: 683-689.

4. Sandilands A, Sutherland C, Irvine AD, McLean WH (2009) Filaggrin in the frontline: role in skin barrier function and disease. J Cell Sci 122: 1285-1294.

5. Papakonstantinou E, Roth M, Karakiulakis G (2012) Hyaluronic acid: A key molecule in skin aging. Dermatoendocrinol 4: 253-258.

6. Tsepilov RN, Beloded AV (2015) Hyaluronic acid-an "Old" molecule with "New" functions: biosynthesis and depolymerization of hyaluronic acid in bacteria and vertebrate tissues including during carcinogenesis. Biochemistry (Mosc) 80: 1093-1108.

7. Choi YJ, Park IS, Kim MH, Kwon B, Choo YM, et al. (2018) The medicinal mushroom Auricularia auricula-judae (Bull.) extract has antioxidant activity and promotes procollagen biosynthesis in HaCaT cells 4: 1-4.

8. Četojević-Simin DD, Čanadanović-Brunet JM, Bogdanović GM, Djilas SM, et al. (2010) Antioxidative and antiproliferative activities of different horsetail (Equisetum arvense L.) extracts. J Med Food 13: 452-459. 


\section{ISSN: 2574-1241}

DOI: 10.26717/BJSTR.2018.09.001790

Jiyoung Kim. Biomed J Sci \& Tech Res

(c) (i) This work is licensed under Creative

Submission Link: https://biomedres.us/submit-manuscript.php

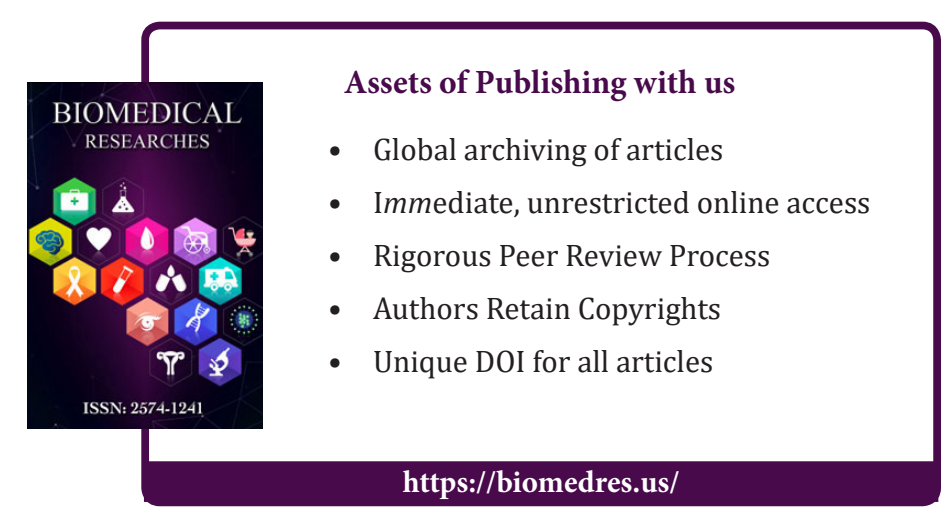

